\title{
PENGARUH PENERAPAN SISTEM E-FILLING TERHADAP KEPATUHAN WAJIB PAJAK ORANG PRIBADI PEGAWAI NEGERI SIPIL DENGAN PEMAHAMAN INTERNET SEBAGAI VARIABEL PEMODERASI
}

(Studi Kasus pada Dinas Perindustrian dan Perdagangan DIY)

\section{THE EFFECT OF E-FILLING SYSTEM APPLICATION ON CIVIL SERVANT PERSONAL TAXPAYERS COMPLIANCE WITH INTERNET LITERACY AS A MODERATE VARIABLE}

(A Case Study at the Department of Industry and Commerce of Special Region of Yogyakarta)

\author{
Yuliano Osvaldo Lado ${ }^{1}$, M. Budiantara ${ }^{2}$ \\ ${ }^{12}$ Program Studi Akuntansi FE Universitas Mercu Buana Yogyakarta \\ ${ }^{2}$ krissnak@gmail.com
}

\begin{abstract}
Abstrak
Penelitian ini bertujuan untuk menganalisis pengaruh Penerapan Sistem EFilling terhadap Kepatuhan WPOP PNS dengan Pemahaman Internet sebagai Variabel Pemoderasi pada Dinas Perindustrian dan Perdagangan DIY. Data penelitian ini diperoleh dari kuesioner (Primer) yang dibagikan kepada WPOP PNS yang bekerja di Dinas Perindustrian dan Perdagangan DIY dengan metode proportionate stratified random sampling. Populasi penelitian ini adalah WPOP PNS di Dinas Perindustrian dan Perdagangan DIY. Sampel yang digunakan pada penelitian ini sebanyak 59 responden. Kuesioner di uji valditas dan uji reliabilitas sebelum penelitian. Uji asumsi klasik yang digunakan adalah uji multikolinieritas, uji heteroskedastisitas, dan uji normalitas. Uji hipotesis yang digunakan adalah regresi linier sederhana dan Moderated Regression Analysis.

Hasil penelitian ini menunjukkan bahwa (1) Penerapan Sistem E-Filling berpengaruh postif dan signifikan terhadap Kepatuhan Wajib Pajak. Hal ini dibuktikan melalui analisis regresi linier sederhana yang diperoleh nilai $R$ Square sebesar 0,138 , yang dapat diartikan bahwa besarnya pengaruh Penerapan Sistem E-Filling terhadap Kepatuhan Wajib Pajak adalah 13,8\%. Hasil uji t statistik menghasilkan nilai signifikansi lebih kecil dari level of significant yaitu $0,004<0,05$. (2) Pemahaman Internet tidak memoderasi pengaruh Penerapan Sistem EFilling terhadap Kepatuhan WPOP PNS. Hal tersebut dibuktikan melalui Moderated Regression Analysis yang memberikan nilai koefisien sebesar $-0,041$, yang dapat diartikan Pemahaman Internet tidak memoderasi pengaruh Penerapan Sistem E-Filling terhadap Kepatuhan WPOP PNS karena hasilnya negatif serta uji t statistik menghasilkan nilai signifikan lebih besar dari level of significant yaitu 0,051 > 0,05 .
\end{abstract}

Kata Kunci: E-Filling, Kepatuhan Wajib Pajak Orang Pribadi PNS, Internet.

\section{Abstract}

This study aims to analyze the influence of E-Filling System Implementation on personal taxpayer compliance of civil servants with the literacy of the Internet as a moderating variable at the Department of Industry and Commerce of Special Region of Yogyakarta. This research data is obtained from questionnaire (Primary) which is distributed to civil servant personal taxpayers working in Department of Industry and Commerce of Special Region of Yogyakarta with proportionate stratified random sampling method. The population of this research is civil servant 
personal taxpayers at the Department of Industry and Commerce of Special Region of Yogyakarta Office. The sample used in this study were 59 respondents. Questionnaires have been tested for validity and reliability tests prior to the study. The classical assumption tests used were multicollinearity test, heteroscedasticity test, and normality test. Hypothesis tests used were simple linier regression and Moderated Regression Analysis. The results of this study indicate that (1) Implementation of E-Filling System positively and significantly influence Taxpayer Compliance. This is proven through simple linear regression analysis obtained $R$ Square value of 0.138 , which can be interpreted that the amount of E-Filling System Implementation influenced 13.8\% Taxpayer Compliance. The results of the statistical t test obtained a significance value smaller than the level of significant that is $0.004<0.05$. (2) Internet literacy does not moderate the influence of E-Filling System Implementation on WPOP PNS Compliance. It is proved through Moderated Regression Analysis which gives coefficient value of -0.041 , which can be interpreted Internet literacy does not moderate influence of Implementation of E-Filling System to Compliance of civil servant personal taxpayers because the result is negative and the t test of statistic produce significant value bigger than level of significant that is 0,051 >0.05.

Keywords: E-Filling, Civil Servants Personal Taxpayer Compliance, Internet.

\section{PENDAHULUAN}

Negara Republik Indonesia adalah negara hukum berdasarkan Pancasila dan Undang-Undang dasar 1945, bertujuan mewujudkan tata kehidupan negara dan bangsa yang adil dan sejahtera, aman, tenteram, dan tertib, serta menjamin kedudukan hukum yang sama bagi warga masyarakat. Untuk mencapai tujuan dimaksud, pembangunan nasional yang dilaksanakan secara berkesinambungan dan berkelanjutan serta merata di seluruh tanah air memerlukan biaya besar yang harus digali terutama dari sumber kemampuan sendiri. Pajak digunakan sebagai salah satu usaha yang digunakan oleh pemerintah untuk mewujudkan kemandirian suatu bangsa atau negara dalam pembiayaan pembangunan yang berguna bagi kepentingan bersama.

Secara umum pajak adalah pungutan dari masyarakat oleh negara (pemerintah) berdasarkan undang-undang yang bersifat dapat dipaksakan dan tergantung oleh yang wajib membayarnya dengan tidak mendapatkan prestasi kembali (kontra prestasi/balas jasa) secara langsung, yang hasilnya digunakan untuk membiayai pengeluaran negara dalam penyelenggaraan pemerintah dan pembangunan, Marihot Pahala Siahaan (2013).

Peraturan perundang-undangan perpajakan selalu mengalami perubahan, tetapi tidak merubah ciri dan corak sistem pemungutan pajak yang berlaku di Negara Indonesia yaitu sistem self assessment, yang artinya suatu sistem dimana Wajib Pajak diberi kepercayaan untuk menghitung sendiri besarnya pajak yang terutang, memperhitungkan besarnya pajak yang sudah dipotong oleh pihak lain, membayar pajak yang harus dibayar dan melaporkan ke Kantor Pajak sesuai dengan ketentuan yang telah ditetapkan dalam peraturan yang berlaku (Diana Sari, 2013). Perlu adanya kesadaran, kejujuran, kedisiplinan oleh warga negara dalam menjalankan kewajiban perpajakan sehingga sistem perpajakan self assesment yang di anut oleh negara Indonesia dapat terus dipakai dan berjalan seperti yang diharapkan karena untuk meningkatkan kesejahteraan masyarakat dalam berbagai bidang dan dalam membiayai segala kebutuhan rumah tangga di negara ini baik APBN ataupun APBD sumber utamanya dari pajak.

Aparatur Sipil Negara (ASN) adalah profesi Pegawai Negeri Sipil dan pegawai pemerintah dengan perjanjian kerja yang bekerja pada instansi pemerintah. Pegawai ASN terdiri dari Pegawai Negeri Sipil dan pegawai pemerintah dengan perjanjian kerja yang diangkat oleh pejabat pembina kepegawaian dan diserahi tugas dalam suatu jabatan pemerintahan atau diserahi tugas negara lainnya dan digaji berdasarkan peraturan perundang-undangan(Wikipedia.com). 
Jenis Pegawai Negeri di atur dalam Pasal 2 ayat (1) UU N0.43 Tahun 1999 Tentang Pokok-pokok Kepegawaian, Pegawai Negeri dibagi menjadi:

1. Pegawai Negeri Sipil(PNS),

2. Anggota Tentara Nasional Indonesia, dan

3. Anggota Kepolisian Negara Republik Indonesia.

Pasal 2 ayat (1) UU No.43 Tahun 1999 tidak menyebutkan apa yang dimaksud dengan pengertian masing-masing bagiannya, namun dapat diambil suatu kesimpulan bahwa yang dimaksud dengan Pegawai Negeri Sipil adalah, Pegawai Negeri yang bukan anggota Tentara Nasional Indonesia dan anggota Kepolisian Republik Indonesia. Berdasarkan penjabaran tersebut, Pegawai Negeri Sipil merupakan bagian dari Pegawai Negeri yang merupakan Aparatur Sipil Negara. Pegawai Negeri Sipil menurut UU No. 43 Tahun 1999 Pasal 2 ayat (1) dibagi menjadi; Pegawai Negeri Sipil Pusat dan Pegawai Negeri Sipil Daerah. Pegawai Negeri Sipil Pusat adalah Pegawai Negeri Sipil yang gajinya dibebankan pada Anggaran Pendapatan dan Belanja Negara. PNS tersebut bekerja pada Departemen, Lembaga Pemerintah Nondepartemen, Kesekretariatan Lembaga Negara, Instansi Vertikal di Daerah Provinsi Kabupaten/Kota, Kepaniteraan Pengadilan, atau dipekerjakan untuk menyelenggarakan tugas lainya. Pegawai Negeri Sipil Daerah adalah Pegawai Negeri Sipil daerah Provinsi/Kabupaten/Kota yang gajinya dibebankan pada Anggaran Pendapatan dan Belanja Daerah dan bekerja pada Pemerintahan daerah, atau dipekerjakan di luar instansi induknya (Muhamad Haryono, 2012).

PNS merupakan agen pemerintah, abdi negara yang diharapkan sepantasnya menjadi panutan rakyat, tolak ukur, teladan dan contoh riil terutama dalam hal menunaikan kewajiban sebagai warga negara Indonesia, khususnya dalam bidang perpajakan,karena segala kegiatan dan pembiayaan di sektor publik sumber dananya dari APBN dan APBD yang berasal dari pajak. Tetapi pada kenyataanya PNS yang merupakan pengguna terbesar dari pajak masih banyak yang tidak patuh terhadap kewajiban perpajakannya hal tersebut dapat terlihat dari banyaknya pemberitaan baik di media cetak dan elektronik dari berbagai daerah di Indonesia mengenai ASN/PNS yang tidak patuh dalam menjalankan kewajiban perpajakannya.

Kepala Kantor Pelayanan Pajak (KPP) Pratama Kupang Benny Perlaungan Sialagan mengatakan tingkat kesadaran dan kepatuhan wajib pajak baik Pajak Penghasilan (PPh) Orang Pribadi dan Badan tahun pajak 2015 di Kupang masih rendah. Tingkat kepatuhan wajib Pajak Penghasilan ( $\mathrm{PPh}$ ) Orang Pribadi diukur dari pencapaian wajib pajak orang yang melapor hingga 1 April 2016 hanya sebanyak 44 persen dari 44.400 total wajib pajak di Kota setempat dari target yang diberikan untuk tahun ini 70 hingga 75 persen. Indikator lain dari tingkat kepatuhan wajib pajak dilihat dari Surat Pemberitahuan Tahunan (SPT) sejumlah Pegawai Negeri Sipil yang sudah dua hingga empat tahun tidak menyampaikan SPTnya sehingga diberi sanksi berupa denda Rp100.000. KPP Pratama Kupang yang membawahi wilayah Kota Kupang, Kabupaten Kupang, Alor, Sabu Raijua dan Rote Ndao wajib pajak dengan profei PNS ketahuan tidak patuh ketika wajib daftar ulang PNS beberapa waktu lalu," katanya. Ia mengatakan terdapat sekitar 700-an PNS dari total 103 wajib pajak yang ada dalam cakupan KPP Pratama Kupang tidak patuh melaporkan SPT-nya sehingga diberikan denda dan totalnya mencapai Rp249 juta yang harus disetorkan ke Kas Negara (Bisnis.com).

Kantor Pelayanan Pajak (KPP) Pratama Baubau telah melayangkan surat kepada Pemerintah Kabupaten Buton Selatan, terkait tagihan kepada wajib pajak kepada para Aparatur Sipil Negara (ASN/PNS) lingkup Pemerintah Kabupaten Buton Selatan, untuk segera melunasi ketunggakan pajak. Tercatat, dari sekitar kurang lebih 2000 ASN/PNS wajib pajak di Busel, sekitar 500 yang tidak melapor ataupun yang terlambat lapor wajib pajak. Jika dirata-ratakan, secara umum ada 75 persen ASN/PNS lingkup Pemkab Busel 
yang sudah patuh terhadap pajak, sedangkan sisahnya belum patuh atas kewajiban bayar pajak Kondisi itu diketahui, saat KPP Pratama Baubau menggelar sosialisasi elektornikfiling kepada seluruh wajib pajak khususnya ASN/PNS lingkup Pemkab Busel, yang digelar di Aaula Gedung Lamaindo Batauga beberapa waktu lalu. Kepala Seksi Waskon II KPP Pratama Baubau Seno Purwanto menyatakan, sosialisasi itu untuk meningkatkan partisipasi wajib pajak dalam melakukan pelaporan SPT dan melakukan e-filling. "Di periode Januari-Maret itu pelaporan SPT tahunan bagi wajib pajak Pribadi dan badan usaha, sementara wajib pajak pribadi sebagian besar adalah ASN/PNS," ucap Seno (baubaupost.com).

Untuk meningkatkan kepatuhan Wajib Pajak, Direktorat Jenderal Pajak selalu berupaya mengoptimalkan pelayanan sehingga diharapkan dapat meningkatkan kesadaran dan keinginan masyarakat untuk tertib sebagai Wajib Pajak, salah satunya dengan melakukan reformasi perpajakan. Pengelolaan penerimaan pajak yang dilakukan melalui reformasi perpajakan mencakup reformasi kebijakan dan administrasi. Pemerintah melaksanakan reformasi perpajakan ini sebenarnya adalah untuk meningkatkan tax ratio. Selain untuk meningkatkan tax ratio, tujuan reformasi dan modernisasi adalah memberikan pelayanan yang lebih baik, nyaman, ramah, mudah, efisien, tidak berbelitbelit, sehingga wajib pajak tidak beranggapan bahwa membayar pajak itu hal yang berbelit-belit yang harus dihindari, Satriyo (2009).

Reformasi kebijakan dalam rangka meningkatkan kepatuhan wajib pajak orang pribadi,khususnya Aparatur Sipil Negara/Anggota Tentara Nasional Indonesia/Kepolisian Republik Indonesia (ASN/PNS/TNI/Polri), khususnya terkait dengan kewajiban perpajakan Kementerian Pendayagunaan Aparatur Negara dan Reformasi Birokrasi telah menerbitkan Surat Edaran Nomor SE/02/M.PAN/3/2009 tanggal 31 Maret 2009,yang intinya agar seluruh pejabat dan ASN mematuhi ketentuan peraturan perpajakan dengan mendaftarkan diri sebagai wajib pajak, membayar pajak, serta mengisi dan menyampaikan SPT Tahunan secara $e$-filling.

Sedangkan reformasi administrasi yang dilakukan oleh Direktorat Jenderal Pajak adalah dengan melakukan perbaikan proses bisnis yaitu memanfaatkan teknologi informasi dan komunikasi dengan menerapkan sistem e-filling. Melalui Keputusan Direktur Jenderal Pajak Nomor Kep-88/PJ/2004 pada bulan Mei tahun 2004 secara resmi diluncurkan produk e-filling. Tepatnya pada tanggal 24 Januari 2005 bertempat di Kantor Kepresidenan, Presiden Republik Indonesia bersama-sama dengan Direktorat Jenderal Pajak meluncurkan produk e-filling atau electronic filling system (Ayu, 2005).

Penerapan sistem e-filling diharapkan dapat memudahkan Wajib Pajak dalam menyampaikan SPT. Namun dalam kenyataannya, masih banyak Wajib Pajak yang belum menggunakan fasilitas tersebut. Berikut ini rasio penggunaan sistem $e$-filling oleh Wajib Pajak Orang Pribadi:

Tabel 1 : Rasio Penggunaan E-Filling

\begin{tabular}{cccccc}
\hline Uraian & $\mathbf{2 0 0 8}$ & $\mathbf{2 0 0 9}$ & $\mathbf{2 0 1 0}$ & $\mathbf{2 0 1 1}$ & $\mathbf{2 0 1 2}$ \\
\hline $\begin{array}{c}\text { SPT Tahunan PPh } \\
\text { WPOP }\end{array}$ & 1.677 .160 & 4.853 .323 & 7.700 .961 & 8.812 .251 & 8.934 .821 \\
$\begin{array}{c}\text { WP yang menggunakan } \\
\begin{array}{c}\text { e-filling } \\
\text { Rasio penggunaan e- } \\
\text { filling }\end{array}\end{array}$ & 1.619 & 2.427 & 4.941 & 9.850 & 21.799 \\
\hline
\end{tabular}

Sumber: Sari Nurhidayah (2015) 
Berdasarkan tabel di atas diketahui sampai tahun 2012 atau selama 8 tahun sistem e-filling diterapkan, belum banyak yang sudah menggunakan sistem tersebut, bahkan dapat dikatakan hanya sebagian kecil saja yang menggunakan e-filling. Hal tersebut terlihat dari rasio penggunaan e-filling oleh Wajib Pajak Orang Pribadi tahun 2008-2012 belum mencampai $1 \%$.

Penggunaan e-filling memanfaatkan jaringan internet, maka untuk dapat menggunakan e-filling Wajib Pajak dituntut untuk dapat mengoperasikan internet. Rendahnya tingkat rasio penggunaan e-filling sampai akhir tahun 2012 dipengaruhi oleh rendahnya faktor pengetahuan terhadap penggunaan internet. Hal tersebut dapat terlihat dari statistik pengguna internet di Pulau Jawa yang merupakan pulau terpadat di Indonesia tersebut terlihat sedikitnya pengguna internet di pula jawa. Salah satu contohnya adalah data pengguna internet di Provinsi Daerah Istimewah Yogyakarta, dimana total populasi masyarakat sebanyak 425.000 jiwa, total pengguna internet sebanyak 164.000 jiwa, sehingga penetrasi pengguna internet di Provinsi Daerah Istimewah Yogyakarta hanya sebesar 38,5\% (Asosiasi Penyelenggara Jasa Internet Indonesia (2012).

Seiring dengan perkembangan dunia teknologi dan informasi, sejak tahun 2014 terdapat peningkatan jumlah pengguna internet di Indonesia. Menurut lembaga riset pasar e-Marketer, populasi netter Tanah Air mencapai 83,7 juta orang pada 2014. Angka yang berlaku untuk setiap orang yang mengakses internet setidaknya satu kali setiap bulan itu mendudukkan Indonesia di peringkat ke-6 terbesar di dunia dalam hal jumlah pengguna internet. Pada 2017, e-Marketer memperkirakan netter Indonesia bakal mencapai 112 juta orang, mengalahkan Jepang di peringkat ke-5 yang pertumbuhan jumlah pengguna internetnya lebih lamban (Kompas.com). Dengan pertumbuhan dan perkembangan pengguna internet yang cukup tinggi dari tahun ke tahun diharapkan juga dapat memberikan dampak positif pada aspek perpajakan, yaitu penerapan sistem $e$-filling yang lebih baik karena pemahaman internet yang sudah semakin baik dilihat dari jumlah penggunanya di Indonesia yang berkembang pesat.

Terdapat beberapa penelitian yang dilakukan oleh peneliti-peneliti terdahulu mengenai kepatuhan Wajib Pajak, diantaranya penelitian yang memiliki hasil sejenis yang dilakukan oleh Nirawan Adiasa (2013), hasil penelitian menunjukan bahwa pemahaman tentang peraturan perpajakan berpengaruh positif terhadap Kepatuhan Wajib Pajak dan penelitian yang dilakukan oleh Sari Nurhidayah (2015), penelitian ini berjudul "Pengaruh Penerapan Sistem E-filling Terhadap Kepatuhan Wajib Pajak dengan Pemahaman Internet sebagai Variabel Pemoderasi pada KPP Pratama Klaten". Hasil penelitian ini menunjukkan bahwa Penerapan Sistem E-Filling berpengaruh postif dan signifikan terhadap Kepatuhan Wajib Pajak dan Pemahaman Internet dapat memoderasi pengaruh Penerapan Sistem E-Filling terhadap Kepatuhan Wajib Pajak.

Penelitian sejenis lainnya dengan hasil yang berbeda,yaitu penelitian yang dilakukan oleh Reza Yunanto (2015) penelitian yang berjudul"Analisis kepatuhan Penyampaian Surat Pemberitahuan Tahunan Pajak Penghasillan Wajib Pajak Orang Pribadi Sebelum dan Sesudah Penerapan E-Filling Melalui Website Direktorat Jenderal Pajak". Hasil penelitian tersebut menyimpulkan bahwa tidak terdapat perbedaan antara kepatuhan penyampaian SPT Tahunan PPh WPOP di KPP Pratama Sleman sebelum dan sesudah penerapan $e$-filling melalui website DJP.

Adapun saran-saran untuk penelitian selanjutnya oleh peneliti terdahulu mengenai sistem $e$-filling dan kepatuhan wajib pajak, diantaranya penelitian yang dilakukan oleh Renda Ramayanti (2015) dengan judul” Pengaruh Penerapan Sistem E-Filling Terhadap Tingkat Kepatuhan Wajib Pajak " (Studi Kasus pada KPP Pratama Bandung-Tegallega) hasil penelitian menunjukan adanya hubungan yang sedang/moderat antara penerapan 
sistem e-filling terhadap tingkat kepatuhan wajib pajak dengan perhitungan korelasi pearson diperoleh nilai sebesar 0,565. Besarnya pengaruh penerapan sitem e-filling terhadap kepatuhan wajib pajak sebesar $31,1 \%$,sedangkan sisanya sebesar 68,9\% dijelaskan oleh variabel lain diluar model penelitian.Dari hasil tersebut maka peneliti menyarankan agar ada penelitian selanjutnya yang menambahkan variabel lain yang mempengaruhi penerapan sistem e-filling terhadap tingkat kepatuhan wajib pajak. Adapun saran dari penelitian yang dilakukan oleh Tresno,dkk (2012) dengan judul penelitian " Pengaruh Persepsi Penerapan Sistem E-Filling Terhadap Tingkat Kepatuhan Wajib Pajak Badan Dengan Perilaku Wajib Pajak Sebagai Variabel Intervening dan Biaya Kepatuhan Sebagai Variabel Moderasi" ( Studi Kasus Pada KPP Pratama Pulogadung Jakarta Timur),yang dalam saran untuk peneliti selanjutnya tertulis bahwa untuk objek ataupun subyek penelitian dengan lokasi yang berbeda, mungkin akan ditemukan hasil yang berbeda pula, sehingga pemilihan variabel menjadi hal yang sangat penting dalam penelitian selanjutnya.

Berdasarkan masalah yang telah dipaparkan diatas, serta uraian dari beberapa penelitian sebelumnya yang memiliki hasil berbeda juga adanya saran-saran dari penelitian terdahulu,maka peneliti tertarik untuk melakukan penelitian yang mengkaji adakah pengaruhnya penerapan sistem e-filling terhadap kepatuhan Wajib Pajak berdasarkan kenyataan bahwa kepatuhan Wajib Pajak masyarakat Indonesia masih rendah khususnya wajib pajak ASN/PNS. Selain itu, peneliti juga ingin meneliti apakah pemahaman terhadap internet dapat memoderasi hubungan antara penerapan sistem $e$ filling dengan kepatuhan wajib pajak karena untuk dapat menggunakan $e$-filling wajib pajak harus dapat mengoperasikan internet. Berdasarkan latar belakang yang telah diuraikan, maka dengan ini peneliti akan melakukan sebuah penelitian yang berjudul "Pengaruh Penerapan Sistem E-Filling terhadap Kepatuhan Wajib Pajak Orang Pribadi Pegawai Negeri Sipil dengan Pemahaman Internet sebagai Variabel Pemoderasi”" (Studi Kasus pada Dinas Perindustrian dan Perdagangan Daerah Istimewa Yogyakarta).

Sesuai latar belakang masalah yang telah dibahas di atas, dapat dirumuskan beberapa masalah dalam penelitian ini yaitu:

1. Apakah Penerapan Sistem E-Filling berpengaruh terhadap Kepatuhan Wajib Pajak Orang Pribadi Pegawai Negeri Sipil di Dinas Perindustrian dan Perdagangan Daerah Istimewa Yogyakarta?

2. Apakah Pemahaman Internet dapat memoderasi hubungan antara Penerapan Sistem E-Filling dengan Kepatuhan Wajib Orang Pribadi Pegawai Negeri Sipil di Dinas Perindustrian dan Perdagangan Daerah Istimewa Yogyakarta?

\section{Pajak}

a. Definisi Pajak

Terdapat bermacam-macam pengertian atau definisi pajak, namun pada hakekatnya maksud dan tujuan dari pajak itu seragam.

Menurut pasal 1 Undang-Undang Nomor 16 tahun 2009 tentang KUP berbunyi: "Pajak adalah kontribusi wajib kepada negara yang terutang oleh orang pribadi atau badan yang bersifat memaksa ]berdasarkan Undang-Undang, dengan tidak mendapat imbalan secara langsung dan digunakan untuk keperluan negara bagi sebesar-besarnya kemakmuran rakyat."

Sedangkan menurut Soeparman Soemahamidjaja (Waluyo dan Wirawan, 2010) "Pajak adalah iuran wajib berupa uang atau barang yang dipungut oleh penguasa berdasarkan norma-norma hukum, guna menutup biaya produksi barang-barang dan jasajasa kolektif dalam mencapai kesejahteraan umum". 
Dari definisi di atas, dapat disimpulkan bahwa pada dasarnya pajak adalah iuran wajib yang disetorkan untuk negara dan bersifat mengikat, dimana negara dapat memaksakan pembayarannya, yang dalam prakteknya penyetor pajak tidak diberikan imbalan dan hasilnya akan digunakan sebesar-besarnya untuk kemakmuran rakyat.

b. Fungsi Pajak

Terdapat dua fungsi pajak, yaitu fungsi budgetair (sumber keuangan negara) dan fungsi regularend (pengatur).

1) Fungsi Budgetair (Sumber Keuangan Negara)

Pajak mempunyai fungsi budgetair, artinya pajak merupakan salah satu sumber penerimaan pemerintah untuk membiayai pengeluaran baik rutin maupun pembangunan. Sebagai sumber keuangan negara, pemerintah berupaya memasukan uang sebanyak-banyaknya untuk kas negara. Upaya tersebut ditempuh dengan cara ekstensifikasi maupun intensifikasi pemungutan pajak melalui penyempurnaan peraturan berbagai jenis pajak seperti Pajak Penghasilan $(\mathrm{PPh})$, Pajak Pertambahan Nilai (PPN), Dan Pajak Penjualan atas Barang Mewah (PPnBM), serta Pajak Bumi dan Bangunan (PBB), dan lain-lain.

2) Fungsi Regularend (Pengatur)

Pajak mempunyai fungsi pengatur artinya, pajak sebagai alat untuk mengatur atau melaksanakan kebijakan pemerintah dalam bidang sosial dan ekonomi, serta mencapai tujuan-tujuan tertentu di luar bidang keuangan. Beberapa contoh penerapan pajak sebagai fungsi pengatur adalah:

a) Pajak yang tinggi dikenakan terhadap barang-barang mewah. Pajak Penjualan atas Barang Mewah dikenakan pada saat terjadi transaksi jual beli barang mewah. Makin mewah suatu barang maka tarif pajaknya makin tinggi sehingga barang-barang tersebut makin mahal harganya. Pengenaan pajak ini dimaksudkan agar rakyatnya tidak belomba-lomba untuk mengkonsumsi barang mewah (mengurangi gaya hidup mewah).

b) Tarif pajak progresif dikenakan atas penghasilan: dimaksudkan agar pihak yang memperoleh penghasilan tinggi memberikan kontribusi(membayar pajak) yang tinggi pula, sehingga terjadi pemerataan pendapatan.

c) Tarif pajak ekspor sebesar 0\%: dimaksudkan agar pengusaha terdorong mengekspor hasil produksinya dipasar dunia sehingga dapat memperbesar devisa negara.

d) Pajak penghasilan dikenakan atas penyerahan barang hasil industri tertentu seperti industri semen, industri rokok, industri baja, dan lain-lain: dimaksudkan agar terdapat penekanan produksi terhadap industri tersebut karena dapat mengganggu lingkungan atau polusi (membahayakan kesehatan)

e) Pembebasan pajak penghasilan atas sisa hasil usaha koperasi: dimaksdukan untuk mendorong perkembangan koperasi di Indonesia.

f) Pemberlakuan tax holiday: dimaksudkan untuk menarik investor asing agar menanamkan modalnya di Indonesia.

3) Pengelompokan Pajak

Menurut Mardiasmo (2011:5), pajak dapat dikelompokkan menjadi tiga kelompok sebagai berikut:

1) Menurut Golongannya

a) Pajak Langsung, yaitu pajak yang harus dipikul sendiri oleh Wajib Pajak dan tidak dapat dibebankan atau dilimpahkan kepada orang lain. Contoh: Pajak Penghasilan. 
b) Pajak Tidak Langsung, yaitu pajak yang pada akhirnya dapat dibebankan atau dilimpahkan kepada orang lain. Contoh: Pajak Pertambahan Nilai.

2) Menurut Sifatnya

a) Pajak Subjektif, yaitu pajak yang berpangkal atau berdasarkan pada subjeknya, dalam arti memperhatikan keadaan diri Wajib Pajak. Contoh: Pajak Penghasilan.

b) Pajak Objektif, yaitu pajak yang berpangkal pada objeknya tanpa memperhatikan keadaan diri Wajib Pajak. Contoh: Pajak Pertambahan Nilai dan Pajak Penjualan atas Barang Mewah.

3) Menurut Lembaga Pemungutannya

a) Pajak Pusat, yaitu pajak yang dipungut oleh pemerintah pusat dan digunakan untuk membiayai rumah tangga negara. Contoh: Pajak Penghasilan, Pajak Pertambahan Nilai, Pajak Penjualan atas Barang Mewah dan Bea Materai.

b) Pajak Daerah, yaitu pajak yang dipungut oleh Pemerintah Daerah dan digunakan untuk membiayai rumah tangga daerah. Pajak Daerah terdiri dari:

- Pajak Propinsi, contoh: Pajak Kendaraanh Bermotor dan Pajak Bahan Bakar Kendaraan Bermotor.

- Pajak Kabupaten/Kota, contoh: Pajak Hotel, Pajak Restoran dan Pajak Hiburan.

4) Sistem Pemungutan Pajak

Menurut Waluyo (2010) Sistem Pemungutan Pajak dapat dibagi menjadi 3 bagian:

1.) Self Assessment System

Sistem pemungutan pajak yang memberi kepercayaan kepada wajib pajak untuk menghitung, memperhitungkan, membayar dan melaporkan sendiri pajak yang terutang.

Ciri self assessment system:

a) Wewenang untuk menentukan besarnya pajak terutang ada pada wajib pajak itu sendiri.

b) Wajib pajak aktif mulai dari menghitung, menyetor dan melaporkan sendiri pajak yang terutang.Fiskus tidak ikut campur dan hanya mengawasi

2.) Official Assessment System.

Sistem pemungutan pajak yang dibayar oleh wajib pajak setelah terlebih dahulu ditetapkan oleh Kepala Daerah atau pejabat yang ditunjuk melalui Surat Ketetapan Pajak Daerah atau dokumen lain yang dipersamakan, seperti karcis dan atau nota pesanan (bill).

Ciri-cirinya:

a) Wewenang untuk menentukan besarnya pajak terutang ada pada fiskus.

b) Wajib pajak bersifat pasif.

c) Utang pajak timbul setelah dikeluarkan surat ketetapan pajak oleh fiskus

3.) Withholding Tax System.

Adalah suatu sistem pemungutan pajak yang memberi wewenang kepada pihak ketiga (bukan fiskus dan bukan wajib pajak yang bersangkutan) untuk menentukan besarnya pajak yang terutang oleh wajib pajak. Ciri-cirinya: Wewenang menentukan besarnya pajak yang terutang adalah pada pihak ketiga, pihak selain fiskus dan wajib pajak. 


\section{Kepatuhan Wajib Pajak}

a. Pengertian Wajib Pajak

Pengertian Wajib Pajak menurut UU No 16 Tahun 2009 tentang Ketentuan Umum dan Tata Cara Perpajakan berbunyi: "Wajib Pajak adalah orang pribadi atau badan, meliputi pembayar pajak, pemotong pajak, dan pemungut pajak, yang mempunyai hak dan kewajiban perpajakan sesuai dengan ketentuan peraturan perundang-undangan perpajakan." Menurut Anastasia Diana dan Lilis Setiawati (2010:1), "Wajib pajak adalah orang pribadi atau badan, meliputi pembayar pajak, pemotong pajak dan pemungut pajak, yang mempunyai hak dan kewajiban perpajakan sesuai dengan ketentuan peraturan perundang-undangan perpajakan.

Menurut Mardiasmo (2016) Wajib Pajak memiliki beberapa kewajiban yang harus dipenuhi yaitu:

1.) Mendaftarkan diri untuk mendapatkan NPWP.

Wajib Pajak wajib mendaftarkan diri ke Kantor Pelayanan Pajak yang berada di wilayah tempat tinggal atau tempat kedudukan Wajib Pajak, kemudian akan diperoleh Nomor Pokok Wajib Pajak (NPWP). NPWP tersebut yang kemudian digunakan sebagai identitas bagi Wajib Pajak. Pendaftaran NPWP dapat dilakukan secara online melalui e-register.

2.) Melaporkan usahanya untuk dikukuhkan sebagai PKP.

Wajib Pajak yang merupakan pengusaha yang dikenakan PPN wajib melaporkan usahanya untuk kemudian dikukuhkan sebagai Pengusaha Kena Pajak (PKP) kepada KPP. Pengukuhan sebagai PKP juga dapat dilakukan secara online melalui $e$ register.

3.) Menghitung pajak terutang, memperhitungkan pajak yang sudah dipotong oleh pihak lain, membayar, dan melaporkan sendiri pajak dengan benar.

Sistem perpajakan di Indonesia menganut self assessment system, sehingga Wajib Pajak diharuskan melakukan penghitungan, pembayaran, dan pelaporan pajak dengan sendiri.

4.) Mengisi dengan benar SPT (SPT diambil sendiri), dan memasukkan ke Kantor Pelayanan Pajak dalam batas waktu yang telah ditentukan.

SPT merupakan surat yang digunakan Wajib Pajak untuk melaporkan penghitungan dan/atau pembayaran objek pajak sesuai dengan ketentuan peraturan perundangundangan. Batas waktu maksimal yang telah ditentukan untuk melaporkan SPT ke Kantor Pajak adalah tiga bulan setelah akhir tahun pajak untuk SPT PPh tahunan Wajib Pajak Orang Pribadi dan empat bulan setelah akhir tahun pajak untuk SPT PPh tahunan Wajib Pajak Badan.

5.) Menyelenggarakan pembukuan/pencatatan.

Pencatatan merupakan kumpulan data mengenai peredaran dan/atau penghasilan bruto yang digunakan untuk penghitungan jumlah pajak yang terutang. Pembukuan adalah pencatatan yang dilakukan secara teratur yang berupa data dan informasi keuangan serta jumlah harga perolehan dan penyerahan barang atau jasa, yang ditutup dengan menyusun laporan keuangan meliputi neraca dan laporan laba rugi untuk periode tahun pajak tersebut.

6.) Apabila diperiksa Wajib Pajak diwajibkan:

a) Memperlihatkan laporan pembukuan atau catatan, dan dokumen-dokumen yang berhubungan dengan penghasilan yang diperoleh, kegiatan usaha, pekerjaan bebas Wajib Pajak, atau objek yangterutang pajak.

b) Memberikan kesempatan untuk memasuki tempat atau ruangan yang diperlukan dan yang dapat memperlancar pemeriksaan. 
7.) Apabila ketika mengungkapkan pembukuan, pencatatan, atau dokumen serta keterangan yang diminta, Wajib Pajak terikat oleh suatu kewajiban untuk merahasiakan, maka kewajiban untuk merahasiakan itu ditiadakan oleh permitaan untuk keperluan pemeriksaan.

Hak-hak Wajib Pajak Menurut Mardiasmo (2011) yaitu:

a) Mengajukan surat keberatan dan surat banding.

Wajib Pajak berhak mengajukan surat keberatan apabila merasa tidak puas dengan ketetapan pajak yang dikenakan kepadanya atau atas pemotongan/pemungutan yang dilakukan oleh pihak ketiga. Apabila Wajib Pajak belum puas dengan hasil surat keputusan keberatan, Wajib Pajak berhak mengajukan surat banding ke Pengadilan Pajak.

b) Menerima tanda bukti pemasukkan SPT.

Tanda bukti pemasukan SPT merupakan tanda bukti diterimanya SPT. Tanda bukti diberikan oleh petugas pajak kepada Wajib Pajak.

c) Melakukan pembetulan SPT yang telah dimasukkan.

Wajib Pajak dapat melakukan pembetulan SPT yang telah dimasukkan dengan menyampaikan pernyataan tertulis sebelum Direktur Jenderal Pajak melakukan pemeriksaan.

d) Mengajukan permohonan penundaan penyampaian SPT.

Wajib Pajak berhak untuk mengajukan permohonan penundaan penyampaian SPT dengan alasan tertentu yang dapat diterima.

e) Mengajukan permohonan penundaan atau pengangsuran pembayaran pajak.

Wajib Pajak berhak untuk mengajukan permohonan penundaan/pengangsuran pembayaran pajak dalam kondisi tertentu.

f) Mengajukan permohonan perhitungan pajak yang dikenakan dalam surat ketetapan pajak.

Wajib Pajak berhak mengajukan permohonan perhitungan pajak kepada Direktorat Jenderal Pajak yang dikenakan dalam surat ketetapan pajak apabila terdapat kesalahan pada ketetapan pajak yang didalamnya tidak ada hubungan persengketaan antara fiskus dengan Wajib Pajak.

g) Meminta pengembalian kelebihan pembayaran pajak.

Wajib Pajak berhak meminta pengembalian kelebihan pembayaran pajak apabila pajak terutang untuk suatu tahun pajak lebih kecil dari jumlah kredit pajak.

h) Mengajukan permohonan penghapusan dan pengurangan sanksi, serta pembetulan surat ketetapan pajak yang salah.

Wajib Pajak berhak mengajukan permohonan penghapusan dan pengurangan sanksi, serta pembetulan surat ketetapan pajak atas kesalahan yang bukan disebabkan oleh Wajib Pajak.

i) Memberi kuasa kepada orang untuk melaksanakan kewajiban pajaknya.

j) Meminta bukti pemotongan atau pemungutan pajak.

Bukti pemotongan atau pemungutan pajak digunakan sebagai pengurang pajak atau kredit pajak bagi pihak yang dipotong di akhir tahun pajak.

b. Pengertian Kepatuhan Wajib Pajak

Budiatmanto (1999) dalam Tjahjono (2006). Menjelaskan bahwa kepatuhan wajib pajak adalah, perilaku wajib pajak dalam memenuhi kewajiban perpajakannya sesuai dengan peraturan yang berlaku (Budiatmanto, 1999 dalam Tjahjono, 2006:29). Menurut Abdul Rahman (2010:32) kepatuhan perpajakan dapat didefinisikan sebagai keadaan dimana Wajib Pajak memenuhi semua kewajiban perpajakan dan melaksanakan hak 
perpajakannya. Dari pengertian diatas dapat disimpulkan bahwa, Kepatuhan wajib paja adalah kondisi dimana wajib pajak mendaftarkan diri, menghitung, menyampaikan dan membayar kewajiban perpajakannya dan menyetorkan kembali surat setoran sesuai peraturan yang berlaku tanpa ada tindakan pemaksaan.

Menurut Burton(2005:4-6), ada beberapa hal yang dapat mempengaruhi kesadaran dan kepatuhan wajib pajak dalam memenuhi kewajiban pajaknya. Adapun faktorfaktornya sebagai berikut:

1.) Tarif pajak.

2.) Pelaksanaan penagihan yang rapih, konsisten dan konsikuen.

3.) Ada tidaknya sanksi bagi pelanggar.

4.) Pelaksanaan sanksi secara konsisten,konsikuen dan tidak pandang bulu.

Undang -undang tidak pernah menegaskan siapa dan bagaimana dari wajib pajak yang tergolong patuh kriteria yang dapat digolongkan wajib pajak patuh hanya diatur dalam Keputusan Mentri Keuangan Nomor 544/KMK.03/2000 yang diubah dengan Keputusan Mentri Keuangan Nomor 235/KMK.03/2003 jo Keputusan Dirjen Pajak Nomor 550 Tahun 2000. Hal ini pun hanya kriteria yang dikaitkan dengan masalah pengambilan pendahuluan kelebihan pembayaran pajak. Sebagaimana diatur dalam pasal 17C UUKUP (Burton, 2005:4-6).

c. Syarat Menjadi Wajib Pajak Patuh

Berdasarkan Peraturan Menteri Keuangan Nomor 74/KMK.03/2012 tentang Wajib Pajak dengan Kriteria Tertentu dalam Rangka Pengembalian Pendahuluan Kelebihan Pembayaran Pajak, Wajib Pajak dengan kriteria tertentu disebut sebagai Wajib Pajak Patuh apabila memenuhi beberapa syarat sebagai berikut:

1.) Tepat waktu dalam menyampaikan Surat Pemberitahuan; tepat waktu dalam penyampaian Surat Pemberitahuan Tahunan dalam tiga tahun terakhir yaitu akhir bulan ketiga setelah tahun pajak.

2.) Tidak mempunyai tunggakan pajak untuk semua jenis pajak, kecuali tunggakan pajak yang telah memperoleh izin menganggur atau menunda pembayaran pajak. Tunggakan pajak adalah angsuran pajak yang belum dilunasi pada saat atau setelah tanggal pengenaan denda.

3.) Laporan keuangan harus diaudit oleh Akuntan Publik atau Lembaga Pengawas Keuangan Pemerintah dengan pendapat Wajar Tanpa Pengecualian selama tiga tahun berturut-turut. Pendapat Wajar Tanpa Pengecualian diberikan oleh auditor apabila tidak ditemukan kesalahan material secara menyeluruh dalam laporan keuangan yang disajikan, dengan kata lain laporan keuangan tersebut sudah sesuai dengan Standar Akuntansi Keuangan (SAK).

4.) Tidak pernah dipidana karena melakukan tindak pidana di bidang perpajakan berdasarkan keputusan pengauditan yang mempunyai kekuatan hukum tetap dalam jangka waktu lima tahun terakhir.

Keuntungan yang diterima apabila menjadi Wajib Pajak patuh adalah mendapatkan pelayanan khusus dalam restitusi pajak penghasilan dan pajak pertambahan nilai yaitu pengembalian pendahuluan kelebihan pajak tanpa harus dilakukan pemeriksaan kepada pengusaha kena pajak.

d. Identifikasi Kepatuhan Wajib Pajak

Menurut Chaizi Nasucha, kepatuhan wajib pajak dapat diidentifikasi dari:

1.) Kepatuhan wajib pajak dalam mendaftarkan diri.

2.) Kepatuhan untuk menyetorkn kembali Surat Pemberitahuan.

3.) Kepatuhan dalam menghitung dan membayar pajak terutang.

4.) Kepatuhan dalam pembayaran tunggakan (Chaizi Nasucha dalam Sony Devano dan Siti Kurnia Rahayu, 2006: 111) Kriteria wajib pajak patuh 
menurut Keputusan Menteri Keuangan No.544/KMK.04/2000, bahwa keriteria kepatuhan wajib pajak adalah:

e. Faktor-Faktor Yang Mempengaruhi Kepatuhan Wajib Pajak

Menurut Widi Widodo (2010: 8) faktor-faktor yang mempengaruhi kepatuhan Wajib Pajak yaitu:

1.) Pengaruh Moralitas

Motivasi yang muncul pada Wajib Pajak, atas kemauan, keyakinan untuk berpartisipasi kepada negara dengan membayar pajak yang dapat dinyatakan sebagai sikap kepatuhan pajak. Moralitas merupakan salah satu aspek dalam kepatuhan pajak, beberapa yang mendasari faktor moralitas yaitu demografis, kebanggaan nasional, partisipasi warga negara, kepercayaan, otonomi daerah, kondisi ekonomi, sistem perpjakan, defference factors.

2.) Pengaruh Budaya

Konsep Budaya Pajak merupakan keseluruhan interaksi formal dan informal dalam suatu institusi yang menghubungkan sistem perpajakan nasional dengan Wajib Pajak dimana secara historis melekat dengan budaya nasional, termasuk ketergantungan dan ikatan yang terbentuk akibat interaksi yang berkelanjutan.

3.) Pengaruh Agama

Indonesia terdapat berbagai keyakinan yang dianut, bukan berarti perbedaan keyakinan tidak menjadikan masyarakat berpecah belah, toleransi antar umat beragama, dan tidak berkaitan dengan pemungutan pajak, dari agama yang dianut.

4.) Pengaruh Pendidikan

Semakin tinggi pendidikan seseorang, maka akan semakin tinggi kesadaran orang untuk membayar pajak, dengan pendidikan yang tinggi maka akan mengerti manfaat pajak dan perolehan pajak yang digunakan untuk pembangunan dan kesejahteraan rakyat. Dari pengertian diatas dapat disimpulkan bahwa kepatuhan wajib pajak dalah:

a) Wajib Pajak wajib mendaftarkan dirinya untuk dapat memenuhi kewajibannya dan menjaga ketertiban pembayaran pajak.

b) Wajib Pajak wajib membayar kewajiban pajaknya pada Kantor Pajak yang ada di daerahnya masing-masing, melalui pihak lain maupun melalui Wajib Pajak sendiri.

c) Wajib Pajak wajib menyampaikan Surat Pemberitahuan yang sudah terdaftar pada Kantor Pajak yang dilengkapi dengan laporan keuangan.

Menurut Abdul Rahman (2010:33) faktor yang mempengaruhi tinggi rendahnya kepatuhan adalah besarnya biaya yang harus dikeluarkan oleh Wajib Pajak, serta waktu yang terpakai oleh Wajib Pajak dalam memenuhi kewajiban perpajakannya, mulai dari waktu membaca formulir SPT dan buku petunjuknya, waktu untuk konsultasi dengan akuntan atau konsultan pajak untuk mengisi SPT, serta waktu yang terpakai untuk pulang pergi ke kantor pajak.

\section{Penerapan Sistem E-Filling}

\section{a. Pengertian E-Filling}

E-Filing adalah suatu cara penyampaian Surat Pemberitahuan (SPT) secara elektronik yang dilakukan secara online dan real time melalui internet pada website Direktorat Jenderal Pajak (http://www.pajak.go.id) atau Penyedia Layanan SPT Elektronik atau Application Service Provider (ASP). E-Filling dijelaskan oleh Gita (2010) sebagai suatu layanan penyampaian SPT secara elektronik baik untuk Orang Pribadi maupun Badan melalui internet pada website Direktorat Jenderal Pajak atau penyedia jasa aplikasi kepada Kantor Pajak dengan memanfaatkan internet, sehingga 
Wajib Pajak tidak perlu mencetak semua formulir laporan dan menunggu tanda terima secara manual.

Menurut Gita (2010) e-filling ini sengaja dibuat agar tidak ada persinggungan Wajib Pajak dengan aparat pajak dan kontrol Wajib Pajak bisa tinggi karena merekam sendiri SPT nya. E-Filling bertujuan untuk mencapai transparansi dan bisa menghilangkan praktek-praktek Korupsi, Kolusi dan Nepotisme (KKN). Dengan diterapkannya sistem e-filling diharapkan dapat memudahkan dan mempercepat Wajib Pajak dalam penyampaian SPT karena Wajib Pajak tidak perlu datang ke Kantor Pelayanan Pajak untuk pengiriman data SPT, dengan kemudahan dan lebih sederhananya proses dalam administrasi perpajakan diharapkan terjadi peningkatan dalam kepatuhan Wajib Pajak. E-Filling juga dirasakan manfaatnya oleh Kantor Pajak yaitu lebih cepatnya penerimaan laporan SPT dan lebih mudahnya kegiatan administrasi, pendataan, distribusi, dan pengarsipan laporan SPT.

Berikut ini proses untuk melakukan e-filling dan tata cara penyampaian SPT Tahunan secara $e$-filling:

1.) Mengajukan permohonan Eletronik Filling Identification Number (EFIN) secara tertulis. EFIN merupakan nomor identitas Wajib Pajak bagi pengguna e-filling. Pengajuan permohonan EFIN hanya dapat dilakukan DJP atau KPP terdekat.

2.) Mendaftarkan diri sebagai Wajib Pajak e-filling paling lambat 30 hari setelah diterbitkannya EFIN. Setelah mendaftarkan diri, Wajib Pajak akan memperoleh username dan password, tautan aktivitas akun e-filling melalui e-mail yang telah didaftarkan oleh Wajib Pajak,dan digital certificate yang berfungsi sebagai pengaman data Wajib Pajak dalam setiap proses $e$-filling .

3.) Menyampaikan SPT Tahunan PPh Wajib Pajak Orang Pribadi melalui situs DJP dengan cara:

a) Mengisi e-SPT pada aplikasi e-filling di situs DJP. E-SPT adalah Surat Pemberitahuan Tahunan (SPT) dalam bentuk formulir elektronik (Compact Disk) yang merupakan pengganti lembar manual SPT.

b) Meminta kode verifikasi untuk pengiriman e-SPT, yang akan dikirimkan melalui email atau SMS.

c) Mengirim SPT secara online dengan mengisikan kode verifikasi.

d) Notifikasi status e-SPT akan diberikan kepada Wajib Pajak melalui email. Bukti Penerimaan e-SPT terdiri dari NPWP (Nomor Pokok Wajib Pajak), tanggal transaksi, jam transaksi, Nomor Transaksi Penyampaian SPT (NTPS), Nomor Transaksi Pengiriman ASP (NTPA), nama Penyedia Jasa Aplikasi (ASP).

4.) Sistem E-Filling melalui website Direktorat Jenderal pajak dapat digunakan untuk:

a) Melayani penyampaian SPT Tahunan PPh WP Orang Pribadi formulir 1770S. SPT ini digunakan bagi Wajib Pajak Orang Pribadi yang sumber penghasilannya diperoleh dari satu atau lebih pemberi kerja dan memiliki penghasilan lainnya yang bukan dari kegiatan usaha dan/atau pekerjaan bebas.

b) Melayani penyampaian SPT Tahunan PPh WP Orang Pribadi Formulir 1770SS. SPT ini digunakan bagi orang pribadi yang sumber penghasilannya dari satu pemberi kerja (sebagai Karyawan) dan jumlah penghasilan brutonya tidak melebihi Rp.60.000.000 (enam puluh juta rupiah) setahun serta tidak terdapat penghasilan lainnya kecuali penghasilan dari bunga bank dan bunga koperasi. 


\section{b. Penerapan Sistem E-Filling}

Pengertian penerapan menurut Kamus Besar Bahasa Indonesia adalah proses, cara, perbuatan menerapkan; pemasangan; pemanfaatan. E-filling merupakan bagian dari sistem dalam administrasi pajak yang digunakan untuk menyampaikan SPT secara online yang realtime kepada kantor pajak. Jadi, penerapan sistem e-filling adalah suatu proses atau cara memanfaatkan sistem yang digunakan untuk menyampaikan SPT secara online yang realtime yang diterapkan oleh Direktorat Jenderal Pajak.

Penerapann sistem e-filling memiliki beberapa keuntungan bagi Wajib Pajak melalui situs DJP yaitu:

1.) Penyampaian SPT lebih cepat karena dapat dilakukan dimana saja dan kapan saja yaitu 24 jam sehari, 7 hari dalam seminggu karena memanfaatkan jaringan internet.

2.) Biaya pelaporan SPT lebih murah karena untuk mengakses situs DJP tidak dipungut biaya.

3.) Penghitungan dilakukan secara cepat karena menggunakan sistem computer.

4.) Lebih mudah karena pingisian SPT dalam bentuk wizard.

5.) Data yang disampaikan Wajib Pajak selalu lengkap karena terdapat validasi pengisian SPT.

6.) Lebih ramah lingkungan karena meminimalisir penggunaan kertas.

7.) Dokumen pelengkap (fotokopi Formulir 1721 A1/A2 atau bukti potong $\mathrm{PPh}, \mathrm{SSP}$ Lembar ke-3 PPh Pasal 29,Surat Kuasa Khusus, perhitungan PPh terutang bagi Wajib Pajak Kawin Pisah Harta dan/atau mempunyai NPWP sendiri, fotokopi Bukti Pembayaran Zakat) tidak perlu dikirim lagi kecuali diminta oleh KPP melalui Account representative.

\section{Pemahaman Internet}

a. Pengertian Internet

Internet (kependekan dari Interconneetion-networking) adalah seluruh jaringan komputer yang saling terhubung menggunakan standar sistem global Transmission Control Protocol/Internet Protocol Suite (TCP/IP) Sebagai protokol pertukaran paket untuk melayani miliaran pengguna di seluruh dunia (Wikipedia). Menurut D.E Conner dalam Ayu Ika Novarina (2005) mendefinisikan internet adalah sistem informasi global berbasis komputer. Internet merupakan jaringan komputer yang saling terkoneksi. Tiap jaringan komputer dapat mencakup puluhan, ratusan bahkan ribuan komputer, dan memungkinkan mereka untuk berbagi informasi satu dengan yang lain dan untuk berbagi sumber-sumber daya komputerisasi seperti super komputer yang kuat dan data base informasi.

b. Manfaat Internet

Pada awalnya, internet dibentuk oleh Departemen Pertahanan Amerika Serikat untuk tujuan militer. Dewasa ini, sesuai dengan perkembangan internet yang sangat pesat, tujuan internet tidak hanya untuk keperluan militer, akan tetapi memberikan banyak manfaat bagi kehidupan sehari-hari, diantaranya:

1.) Memperoleh informasi

Internet sangat bermanfaat dalam kehidupan sehari-hari, salah satunya memberikan informasi yang dibutuhkan pengguna. Dengan adanya internet, pengguna dapat dengan mudah memperoleh berbagai informasi, contohnya adalah informasi mengenai prosedur penggunaan dan perkembangan $e$-filling

2.) Menambah pengetahuan

Di dalam kehidupan sehari-hari, seseorang memerlukan banyak pengetahuan. Internet meberikan kebebasan akses untuk kita mencari atau mendapatkan pengetahuan yang diperlukan, sebagai contoh adalah pengetahuan mengenai 
Peraturan Perundang-undangan. Pengetahuan tersebut akan sangat bermanfaat bagi Wajib Pajak.

3.) Memberikan kecepatan untuk mengaksesnya.

Internet memberikan kecepatan dalam mengakses berbagai informasi, pengetahuan dan kepentingan lainnya. Contohnya adalah dengan adanya internet akan memudahkan dan mempercepat wajib pajak dalam mengakses $e$-filling dan menerima verifikasinya.

\section{Aspek Kewajiban Perpajakan PPh Tahunan WP Orang Pribadi PNS dengan Self Assessment System}

Aspek perpajakan ini merupakan pengenaan PPh Tahunan WP Orang Pribadi PNS yang menerapkan kewajiban self assessment dalam hal penghitungan, pembayaran dan pelaporan PPh tersebut.Dalam menyelesaikan kewajiban ini, WP Orang Pribadi PNS wajib melaporkan seluruh penghasilannya selain penghasilan dari pekerjaannya sebagai PNS.Pelaporan seluruh penghasilan ini masih sering diabaikan oleh PNS yang disebabkan oleh ketidak pahaman atas aturan. (Fatima Hayati,dkk, 2012)

\section{a. Penghitungan}

Objek Pajak Meliputi:

1.) Penghasilan neto dari negeri dari usaha dan/atau pekerjaan bebas. Penghitungan penghasilan neto ini berdasarkan jenis WP yaitu WP yang menyelenggarakan pembukuan dan WP yang menggunakan norma penghitungan penghasilan neto.

2.) Penghasilan neto dalam negeri sehubungan dengan pekerjaan. Penghasilan neto ini merupakan penghasilan WP dari pekerjaannya sebagai PNS yang penghitungannya berdasarkan Formulir 1721 - A2 yang merupakan bukti pemotongan $P P h$ Pasal 21 bagi pegawai negeri sipil

3.) Penghasilan dalam negeri lainnya

4.) Penghasilan neto luar negeri .

Adapun yang dimaksud penghasilan yang tidak termasuk objek pajak adalah:

1.) Bantuan/sumbangan/hibah

2.) Warisan

3.) Bagian laba anggotan perseroan komanditer tidak atas saham, persekutuan, perkumpulan, firma, kongsi

4.) Klaim asuransi kesehatan, kecelakaan, jiwa, dwiguna, beasiswa

5.) Beasiswa dalam negeri

6.) Penghasilan lainnya yang tidak termasuk objek pajak.

Pengurangan Meliputi:

1.) Zakat atau sumbangan yang bersifat wajib

2.) Kompensasi kerugian

3.) Penghasilan tidak kena pajak (PTKP)

Penghitungan dijelaskan sebagai berikut:

1.) $\mathrm{PPh}$ Terhutang dihitung berdasarkan Tarif PPh Pasal 17 dikalikan Penghasilan Kena Pajak (penghasilan neto - zakat/sumbangan yang bersifat wajib kompensasi kerugian - PTKP).

2.) $\mathrm{PPh}$ Kurang/Lebih Bayar dihitung dari $\mathrm{PPh}$ Terhutang setelah dikurangi dengan $\mathrm{PPh}$ yang dipotong / dipungut oleh pihak lain, $\mathrm{PPh}$ yang dibayar / dipotong di luar negeri dan $\mathrm{PPh}$ ditanggung oleh pemerintah serta $\mathrm{PPh}$ yang dibayar sendiri meliputi: PPh Pasal 25 Bulanan, STP PPh Pasal 25 (hanya pokok pajak) dan fiscal luar negeri.

3.) Selain itu dihitung Angsuran PPh Pasal 25 tahun pajak berikutnya berdasarkan:

- Jumlah PPh yang harus dibayar sendiri dibagi 12 bulan 


\section{b. Pembayaran}

- Penghitungan WP Orang Pribadi PNS dengan usaha tertentu.

WP Orang Pribadi PNS terkait dengan pembayaran dapat dilakukan dengan beberapa kondisi:

1.) Bila WP tersebut tidak memiliki penghasilan lainnya di luar pekerjaannya sebagai PNS, maka dari penghitungan tidak akan menghasilkan PPh Kurang / Lebih Bayar atau Nihil sehingga tidak perlu dilakukan pembayaran tetapi tetap melakukan pelaporan.

2.) Bila WP tersebut memiliki penghasilan lainnya di luar pekerjaannya sebagai PNS, maka dari penghitungan akan menghasilan PPh Kurang / Lebih Bayar. Atas PPh Kurang Bayar tersebut mewajibkan WP untuk melakukan pembayaran paling lambat sebelum dilakukan pelaporan dimana batas waktu pelaporan akhir bulan ketiga setelah tahun pajak berakhir atau 31 Maret tahun pajak berikutnya. Sementara untuk PPh Lebih Bayar memungkinkan WP untuk melakukan restitusi atau kompensasi mengikuti ketentuan yang berlaku.

Dalam melakukan pembayaran WP Orang Pribadi PNS menggunakan Surat Setoran Pajak (SSP) yang terdiri dari rangkap 4 (empat). Pembayaran dilakukan pada Kas Negara melalui Kantor Pos atau Bank Presepsi (yang ditunjuk sebagai kantor penerima pajak).

\section{c. Pelaporan}

WP Orang Pribadi PNS dalam melaporkan PPh Tahunan mengunakan:

1.) Formulir 1770 SPT Tahunan PPh WP Orang Pribadi yang digunakan oleh WP Orang Pribadi yang mempunyai penghasilan:

a.) Dari usaha/pekerjaan bebas yang menyelenggarakan pembukuan atau norma penghitungan penghasilan neto

b.) Dari satu atau lebih pemberi kerja

c.) Yang dikenakan PPh Final dan/atau bersifat final

d.) Dari penghasilan lain.

Formulir ini dilampiri dengan Formulir 1770-I, Formulir 1770-II, Formulir 1770-III, dan Formulir 1770-IV.

2.) Formulir $1770 \mathrm{~S}$ SPT Tahunan PPh WP Orang Pribadi yang digunakan oleh WP Orang Pribadi yang mempunyai penghasilan:

a.) Dari satu atau lebih pemberi kerja

b.) Dalam negeri lainnya

c.) Yang dikenakan PPh Final dan/atau bersifat final.

Formulir ini dilampiri dengan Formulir 1770 S-I dan Formulir 1770 S-II.

3.) Formulir 1770 SS yang digunakan oleh WP Orang Pribadi yang mempunyai penghasilan :

a.) Dari satu pemberi kerja dengan penghasilan bruto tidak melebihi Rp. 60.000 .000 dan

b.) Tidak mempunyai penghasilan lain kecuali bunga bank dan/atau bunga koperasi.

Pelaporan SPT PPh Tahunan tersebut disampaikan ke Kantor Pelayanan Pajak tempat WP Orang Pribadi terdaftar atau Pelaporan SPT pada tempat lain yang ditunjuk sebagai tempat penerimaan pelaporan SPT .

Adapun lampiran yang harus dilengkapi selain lampiran yang telah disebutkan di atas, antara lain: Fotokopi formulir bukti pemotongan 1721-A2 PPh Pasal 21 PNS sebanyak 1 lembar (yang diterima dari pemotong pajak) dan SSP lembar ke-3 PPh Pasal 29 bila SPT PPh Tahunan WP Orang Pribadi menunjukan PPh Kurang Bayar. 
Selain itu dalam hal penerapan self assessment system, WP Orang Pribadi PNS berhak secara aktif melakukan:

a) Permintaan bukti pemotongan $\mathrm{PPh}$ Pasal 21 kepada pemotong pajak.

b) Pengajuan surat keberatan kepada Direktur Jenderal Pajak, jika PPh Pasal 21 yang dipotong oleh pemotong pajak tidak sesuai dengan aturan yang berlaku.

c) Pengajuan permohonan banding secara tertulis dalam bahasa Indonesia dengan alasan yang jelas kepada Badan Penyelesaian Sengketa terhadap keputusan mengenai keberatannya yang ditetapkan oleh Direktur Jenderal Pajak.

\section{PARADIGMA PENELITIAN}

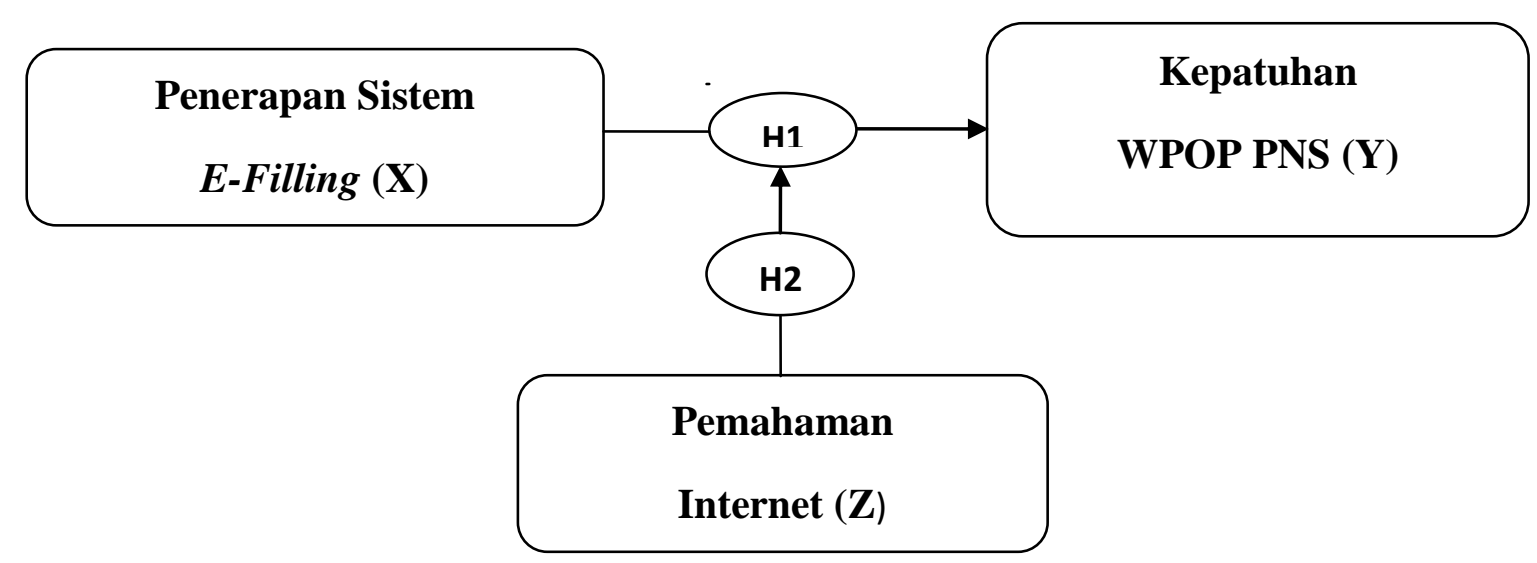

Gambar 1. Paradigma Penelitian

\section{HIPOTESIS PENELITIAN}

Hipotesis biasa digunakan dalam sebuah penelitian. Hipotesis merupakan dugaan sementara yang mungkin benar atau mungkin juga salah. Dia akan ditolak jika salah dan akan diterima jika fakta-fakta membenarkannya.

Penerapan sistem $e$-filling adalah suatu proses atau cara memanfaatkan sistem yang digunakan untuk menyampaikan SPT secara online yang realtime yang diterapkan oleh Direktorat Jenderal Pajak. Sistem e-filling diterapkan oleh Direktoat Jenderal Pajak sebagai upaya dalam mengoptimalkan pelayanan sehingga diharapkan dapat meningkatkan kesadaran dan keinginan masyarakat sebagai wajib pajak. Kepatuhan Perpajakan merupakan ketaatan, tunduk dan patuh serta melaksanakan ketentuan perpajakan. Kepatuhan memenuhi kewajiban perpajakan secara sukarela merupakan tulang punggung sistem self assessment, dimana Wajib Pajak bertanggung jawab menetapkan sendiri kewajiban perpajakan dan kemudian secara akurat dan tepat waktu membayar dan melaporkan pajaknya tersebut.

Penelitian yang dilakukan oleh Sari Nurhidayah berjudul "Pengaruh Penerapan Sistem Efilling Terhadap Kepatuhan Wajib Pajak dengan Pemahaman Internet sebagai Variabel Pemoderasi pada KPP Pratama Klaten". Hasil penelitian ini menunjukkan bahwa Penerapan Sistem E-Filling berpengaruh postif dan signifikan terhadap Kepatuhan Wajib Pajak.

Adapun penelitian yang dilakukan oleh Wulandari Agustiningsih (2016), Penelitian yang berjudul "Pengaruh Penerapan E-Filling, Tingkat Pemahaman Perpajakan dan Kesadaran Wajib Pajak Terhadap Kepatuhan Wajib Pajak di KPP Pratama Yogyakarta". Hasil dari penelitian ini menunjukan bahwa penerapan $e$-filing berpengaruh positif dan signifikan terhadap kepatuhan wajib pajak di KPP Pratama Yogyakarta. 
Dari hasil 2 penelitian diatas maka dalam penelitian ini dapat dirumuskan hipotesis sbb:

\section{H1: Penerapan Sistem E-Filling berpengaruh Positif dan Signifikan terhadap Kepatuhan Wajib Orang Pribadi Pegawai Negeri Sipil di Dinas Perindustrian dan Perdagangan Daerah Istimewa Yogyakarta}

Penggunaan e-filling memanfaatkan jaringan internet, maka untuk dapat menggunakan e-filling Wajib Pajak dituntut untuk dapat mengoperasikan internet. Pemahaman terhadap penggunaan internet dapat memperkuat bahkan memperlemah pengaruh penggunaan $e$-filling terhadap kepatuhan wajib pajak.

Penelitian yang dilakukan oleh Sari Nurhidayah (2015) berjudul "Pengaruh Penerapan Sistem Efilling Terhadap Kepatuhan Wajib Pajak dengan Pemahaman Internet sebagai Variabel Pemoderasi pada KPP Pratama Klaten". Hasil penelitian ini menunjukan pemahaman internet dapat memoderasi pengaruh penerapan sistem e-filling terhadap Kepatuhan Wajib Pajak. Hal tersebut dibuktikan melalui Moderated Regression Analysis yang memberikan nilai koefisien sebesar 0,071, yang dapat diartikan Pemahaman Internet dapat memoderasi pengaruh Penerapan Sistem E-Filling terhadap Kepatuhan Wajib Pajak sebesar $71 \%$. Hasil uji t statistik menghasilkan nilai signifikan lebih kecil dari level of significant yaitu $0,005<0,05$.

Berdasarkan hasil penelitian terdahulu maka dalam penelitian ini dapat dirumuskan hipotesis sbb:

H2: Pemahaman Internet memoderasi Pengaruh Penerapan Sistem E-Filling Terhadap Kepatuhan Wajib Pajak Orang Pribadi Pegawai Negeri Sipil di Dinas Perindustrian dan Perdagangan Daerah Istimewa Yogyakarta

\section{METODE}

\section{Jenis Penelitian}

Penelitian ini merupakan jenis penelitian yang menggunakan metode penelitian kuantitatif dengan bentuk penelitian survai. Menurut Sugiyono (2013: 14) penelitian kuantitatif bertujuan untuk menunjukkan hubungan antar variabel, menguji teori dan mencari generalisasi yang mempunyai nilai prediktif. Penelitian survai merupakan suatu teknik pengumpulan informasi yang dilakukan dengan cara menyusun daftar pertanyaan yang diajukan pada responden. Terdapat 3 jenis penelitian survai yaitu melalui surat/kuesioner, wawancara baik tatap muka lansung atau menggunakan media (misal: telepon), (wikipedia, 2017).

Penelitian ini juga menggunakan variabel moderating, yaitu tipe variabel-variabel yang memperkuat atau memperlemah hubungan langsung antara variabel independen dengan variabel dependen yang mempunyai pengaruh terhadap sifat atau arah hubungan antar variabel (Nur dan Bambang, (2011).

Sumber data yang digunakan dalam penelitian ini adalah data primer. Data primer adalah data yang diperoleh langsung dari subyek penelitian dengan menggunakan alat pengukuran atau pengambilan data (Riwidikdo, 2013; Saryono, 2010). Data primer yang didapat oleh peneliti adalah data langsung dari pengisian kuiesioner yang berisi pertanyaan tentang pengaruh penerapan sistem e-filling terhadap kepatuhan wajib pajak orang pribadi PNS dengan pemahaman internet sebagai variabel pemoderasi . 


\section{Tempat dan Waktu Penelitian}

Penelitian ini dilakukan di Dinas Perindustrian dan Perdagangan Daerah Istimewa Yogyakarta. Waktu pelaksanaan penelitian yaitu dimulai tanggal 19 April sampai dengan tanggal 19 Mei 2017.

\section{Variabel Penelitian}

Pengertian variabel penelitian menurut Juliansyah (2011:47) Variabel penelitian merupakan kegiatan menguji hipotesis, yaitu menguji kecocokan antara teori dan fakta empiris di dunia nyata. Penelitian ini menggunakan tiga jenis variabel yaitu variabel dependen, variabel independen dan variabel pemoderasi. Variabel terikat/ dependen dalam penelitian ini adalah Kepatuhan Wajib Pajak Orang Pribadi PNS, variabel bebas / independen dalam penelitian ini adalah Penerapan Sistem E-Filling dan variabel pemoderasi dalam penelitian ini adalah Pemahaman Internet.

\section{a. Variabel Dependen}

Definisi variabel dependent menurut Sugiyono (2012:39) adalah sebagai variabel tidak bebas/dependet merupakan variabel yang dipengaruhi atau yang menjadi akibat, karena adanya variabel bebas. Variabel dependen dalam penelitian ini adalah Kepatuhan Wajib Pajak Orang Pribadi PNS. Indikator KepatuhanWajib Pajak menurut Sri dan Ita (2009) adalah sebagai berikut:

a. Kepatuhan untuk mendaftarkan diri.

b. Kepatuhan dalam pembayaran tunggakan pajak.

c. Kepatuhan untuk menyetorkan kembali Surat Pemberitahuan.

Ketiga indikator tersebut digunakan sebagai indikator untuk pengukuran Kepatuhan Wajib Pajak. Indikator tersebut diukur dengan menggunakan skala likert 1-4 untuk mengukur jawaban dari responden yang berupa pernyataan sangat tidak setuju, tidak setuju, setuju, dan sangat setuju (Sari Nurhidayah, 2015).

\section{b. Variabel Independen}

Variabel independen atau variabel bebas adalah yang mempengaruhi timbulnya variabel terikat . Variabel independen dalam penelitian ini adalah Penerapan Sistem $E$ Filling. yaitu:

Terdapat beberapa keuntungan diterapkannya sistem e-filling bagi Wajib Pajak

a. Penyampaian SPT dapat dilakukan secara cepat, aman, dan kapan saja (24 jam dalam 7 hari).

b. Penghitungan dapat dilakukan dengan cepat dan akurat karena terkomputerisasi.

c. Mengisi SPT lebih mudah karena pengisian SPT dalam bentuk wizard.

d. Data yang disampaikan Wajib Pajak selalu lengkap karena adanya validasi pengisian SPT.

e. Lebih ramah lingkungan karena meminimalisir penggunaan kertas.

f. Tidak merepotkan karena dokumen pelengkap tidak perlu dikirim kembali kecuali diminta oleh KPP melalui Account Representative (AR).

Keenam keuntungan tersebut digunakan sebagai indikator, sebagai dasar untuk pengukuran Penerapan Sistem E-Filing. Indikator tersebut diukur dengan menggunakan skala likert 1-4 untuk mengukur jawaban dari responden yang berupa pernyataan sangat tidak setuju, tidak setuju, setuju, dan sangat setuju (Sari Nurhidayah, 2015). 


\section{c. Variabel Pemoderasi}

Variabel pemoderasi adalah jenis variabel yang mempengaruhi (memperkuat atau memperlemah) hubungan langsung antara variabel independen dengan variabel dependen. Dalam penelitian ini yang digunakan sebagai variabel pemoderasi adalah Pemahaman Internet. Pemahaman Internet adalah mengerti benar tentang apa itu internet dan mengetahui bagaimana cara menggunakan internet. Internet memberikan beberapa manfaat bagi kehidupan sehari-hari, diantaranya:

a. Memperoleh informasi.

b. Menambah pengetahuan.

c. Kecepatan mengakses.

Ketiga manfaat tersebut digunakan sebagai indikator, sebagai dasar untuk pengukuran Pemahaman Internet. Indikator tersebut diukur dengan menggunakan skala likert 1-4 untuk mengukur jawaban dari responden yang berupa pernyataan sangat tidak setuju, tidak setuju, setuju, dan sangat setuju (Sari Nurhidayah, 2015).

\section{Populasi dan Sampel}

\section{a. Populasi}

Populasi merupakan keseluruhan sumber data yang diperlukan dalam suatu penelitian yang sangat penting dan menentukan suatu keakuratan hasil penelitian (Dharma, 2011; Saryono, 2011). Populasi dalam penelitian ini adalah seluruh Wajib Pajak Orang Pribadi Pegawai Negeri Sipil di Dinas Perindustrian dan Perdagangan Daerah Istimewa Yogyakarta yang berjumlah 143 orang.

b. Sampel

Sampel adalah sebagian dari populasi yang mewakili suatu populasi sebagai sumber data (Machfoedz, 2007). Teknik pengambilan sampel yang digunakan dalam penelitian ini adalah proportionate stratified random sampling. Teknik ini digunakan bila populasi mempunyai anggota/unsur yang tidak homogen dan berstrata secara proporsional. Pertimbangan tertentu dalam memilih sampel pada penelitian ini adalah responden yang diminta untuk mengisi kuesioner harus memenuhi kriteria yaitu:

1.) Responden berstatus sebagai Pegawai Negerei Sipil (PNS) yang bekerja di Dinas Perindustrian dan Perdagangan DIY

2.) Responden pernah menggunakan Sistem E-Filling.

Dalam menentukan jumlah sampel dalam penelitian ini menggunakan rumus Slovin ( Durotun, 2016), sebagai berikut:

$$
n=\frac{N}{N\left(x d^{2}\right)+1}
$$

Keterangan :

$\mathrm{n}$ : jumlah sampel

$\mathrm{N}$ : jumlah populasi

$\mathrm{d}$ : presentase kelonggaran ketidaktelitian karena kesalahan sampel yang masih bisa ditolerir (10\%).

Dengan jumlah populasi sebanyak 143 orang dan tingkat kepercayaan 90\% atau tingkat kesalahan $10 \%$ maka jumlah sampel yang digunakan adalah sebanyak:

$$
\begin{aligned}
& n=\frac{143}{143\left(0,1^{2}\right)+1} \\
& n=58,84 \\
& n=59
\end{aligned}
$$


Dengan tidak mengabaikan keberwakilan sampel yang diteliti, peneliti membagi strata populasi berdasarkan pendidikan terakhir yang ada dalam perhitungan jumlah sampelnya. Sehingga jumlah sampel yang akan digunakan dalam penelitian ini adalah:

Tabel 2. Jumlah dan Keberwakilan Sampel Berdasakan Pendidikan Terakhir

\begin{tabular}{cccc}
\hline No & $\begin{array}{c}\text { Pendidikan } \\
\text { Terakhir }\end{array}$ & $\begin{array}{c}\text { Jumlah PNS } \\
\text { Disperindag DIY }\end{array}$ & Jumlah Sampel \\
\hline 1 & SD & 8 & $\frac{8}{143} \times 59=3,30 \approx \mathbf{3}$ \\
2 & SLTP & 7 & $\frac{7}{143} \times 59=2,88 \approx \mathbf{3}$ \\
3 & SLTA & 85 & $\frac{85}{143} \times 59=35,06 \approx \mathbf{3 5}$ \\
4 & D3 & 3 & $\frac{3}{143} \times 59=1,23 \approx \mathbf{2}$ \\
5 & S1 & 30 & $\frac{30}{143} \times 59=12,37 \approx \mathbf{1 2}$ \\
6 & S2 & 10 & $\frac{10}{143} \times 59=4,12 \approx \mathbf{4}$ \\
& & $\mathbf{1 4 3}$ & $\mathbf{5 9}$ \\
\hline
\end{tabular}

Sumber: Data Primer yang Diolah, 2017

\section{HASIL DAN PEMBAHASAN}

1. Penerapan Sistem E-Filling berpengaruh terhadap Kepatuhan Wajib Pajak Orang Pribadi PNS

Hasil penelitian ini mendukung hipotesis pertama yang menyatakan Penerapan Sistem E-Filling berpengaruh positif dan signifikan terhadap Kepatuhan Wajib Pajak. Hal ini dapat dibuktikan dengan hasil penelitian yang menunjukkan arah model regresi ini adalah positif dengan nilai koefisien korelasi (R) bernilai positif sebesar 0,371 dan $R$ square (R2) sebesar 0,138 yang berarti Penerapan Sistem E-Filling memiliki pengaruh positif dan berpengaruh sebesar 13,8\% terhadap Kepatuhan Wajib Pajak Orang Pribadi PNS dengan nilai signifikansi sebesar 0,004 lebih kecil dari 0,05.

Penerapan Sistem E-Filling memberikan pengaruh signifikan tetapi tidak dominan terhadap Kepatuhan Wajib Pajak karena Penerapan Sistem E-Filling merupakan salah satu dari beberapa upaya yang dilakukan Direktorat Jenderal Pajak dalam meningkatkan Kepatuhan Wajib Pajak.

E-filling merupakan bagian dari reformasi administrasi perpajakan yang bertujuan untuk memudahkan Wajib Pajak dalam pembuatan dan penyerahan laporan SPT kepada Direktorat Jenderal Pajak. Penerapan Sistem E-filling diharapkan dapat memberikan kenyaman dan kepuasan bagi Wajib Pajak dalam memenuhi kewajiban perpajakannya sehingga dengan diterapkannya sistem e-filling diharapkan dapat meningkatkan Kepatuhan Wajib Pajak.

Hasil penelitian ini mendukung hasil penelitian dari Wulandari Agustiningsih (2016) berjudul "Pengaruh Penerapan E-Filling, Tingkat Pemahaman Perpajakan dan Kesadaran Wajib Pajak Terhadap Kepatuhan Wajib Pajak di KPP Pratama Yogyakarta" Dalam penelitian yang dilakukan oleh Wulandari Agustiningsih, Hasil dari penelitian tersebut menunjukan bahwa Penerapan e-filing berpengaruh positif dan signifikan terhadap kepatuhan wajib pajak di KPP Pratama Yogyakarta. Hal ini ditunjukan dengan 
nilai Koefisien determinasi 0,454 yang berarti bahwa penerapan e-filing mempengaruhi kepatuhan wajib pajak sebesar $45,4 \%$..

Hasil penelitian ini mengindikasikan bahwa Penerapan Sistem E-filling berpengaruh positif terhadap Kepatuhan Wajib Pajak. Semakin baik Penerapan Sistem $E$ Filling maka Kepatuhan Wajib Pajak akan semakin meningkat.

\section{Pemahaman Internet tidak memoderasi pengaruh Penerapan Sistem E-Filling terhadap Kepatuhan Wajib Pajak Orang Pribadi PNS}

Hasil penelitian ini menolak hipotesis kedua yang menyatakan Pemahaman Internet dapat memoderasi pengaruh Penerapan Sistem Efilling terhadap Kepatuhan Wajib Pajak Orang Pribadi PNS. Hal ini dapat dibuktikan dengan nilai moderat koefisien regresi yang bernilai negatif sebesar -0,041 dengan nilai signifikan sebesar 0,051 lebih besar dari 0,05 yang berarti dalam penelitian ini pemahaman internet tidak memoderasi pengaruh penerapan sistem $e$-filling terhadap Kepatuhan Wajb Pajak Orang Pribadi PNS di Disperindag DIY.

Hasil penelitian ini yang menolak hipotesis 2 yaitu pemahaman internet tidak berpengaruh dalam hubungan penerapan sistem $e$-filling terhadap kepatuhan WPOP PNS, hal ini bisa disebabkan karena sistem $e$-filling dianggap tidak mudah untuk dipelajari bagi pemula meskipun WPOP PNS tersebut memiliki pemahaman internet yang baik, serta penyampaian SPT melalui e-filling bisa dilakukan oleh siapa saja sehingga bagi WPOP PNS yang tidak paham internet dapat meminta bantuan orang lain dalam penyampaian SPT melalui sistem $e$-filling.

Hasil penelitian ini yang menunjukan perbedaan dengan hasil penelitian Sari Nurhidayah (2015) yang berjudul " Pengaruh Penerapan Sistem E-Filling Terhadap Kepatuhan Wajib Pajak dengan Pemahaman Internet Sebagai Variabel Pemoderasi Pada KPP Pratama Klaten", semakin memperkuat saran yang dikemukakan oleh Tresno,dkk (2012) dalam penelitiannya dengan judul penelitian “ Pengaruh Persepsi Penerapan Sistem E-Filling Terhadap Tingkat Kepatuhan Wajib Pajak Badan Dengan Perilaku Wajib Pajak Sebagai Variabel Intervening dan Biaya Kepatuhan Sebagai Variabel Moderasi" ( Studi Kasus Pada KPP Pratama Pulogadung Jakarta Timur), yang dalam saran untuk peneliti selanjutnya tertulis bahwa untuk objek ataupun subyek penelitian dengan lokasi yang berbeda, mungkin akan ditemukan hasil yang berbeda pula .

\section{KESIMPULAN}

Berdasarkan analisis data peneliti maka diambil kesimpulan sebagai berikut:

a. Penerapan Sistem E-Filling berpengaruh positif dan signifikan terhadap Kepatuhan Wajib Pajak. Hal ini dapat dibuktikan dengan hasil penelitian yang menunjukkan arah model regresi ini adalah positif dengan nilai koefisien korelasi (R) bernilai positif sebesar 0,371 dan $R$ square (R2) sebesar 0,138 yang berarti Penerapan Sistem $E$ Filling memiliki pengaruh positif dan berpengaruh sebesar 13,8\% terhadap Kepatuhan Wajib Pajak Orang Pribadi PNS dengan nilai signifikansi sebesar 0,004 lebih kecil dari 0,05 .

b. Pemahaman Internet tidak dapat memoderasi pengaruh Penerapan Sistem Efilling terhadap Kepatuhan Wajib Pajak Orang Pribadi PNS. Hal ini dapat dibuktikan dengan nilai moderat koefisien regresi yang bernilai negatif sebesar $-0,041$ dengan nilai signifikan sebesar 0,051 lebih besar dari 0,05 yang berarti dalam penelitian ini Pemahaman internet tidak memoderasi pengaruh Penerapan Sistem E-Filling terhadap Kepatuhan Wajb Pajak Orang Pribadi PNS di Disperindag DIY. 


\section{Keterbatasan Penelitian}

Penelitian ini telah diusahakan untuk dilaksanakan dengan benar dan sesuai dengan prosedur ilmiah, namun demikian masih memiliki keterbatasan yang dapat digunakan sebagai acuan penelitian selanjutnya supaya diperoleh hasil yang lebih baik. Berikut ini keterbatasan-keterbatasan dalam penelitian ini:

a. Penelitian ini hanya dilakukan pada Wajib Pajak Orang Pribadi PNS yang bekerja di Dinas Perindustrian dan Perdagangan DIY, dimana jumlah populasi atau keseluruhan PNS Disperindag DIY sebanyak 143 orang, dan hanya 59 PNS yang dapat dijadikan responden dalam sampel penelitian.

b. Teknik pengumpulan data pada penelitian ini menggunakan kuesioner sehingga data yang dihasilkan mempunyai kesempatan terjadi bias. Kemungkinan terjadi bias disebabkan adanya perbedaan persepsi antara peneliti dengan responden terhadap pertanyaan-pertanyaan yang diajukan.

\section{Saran}

Dari hasil Penelitian dalam skripsi ini, penulis dapat memberikan saran yang diharapkan dapat bermanfaat bagi pihak yang membutuhkan. Saran dari penulis adalah sebagai berikut:

a. Perlu adanya sosialisasi yang berulang dari Direktorat Jenderal Pajak mengenai penyampaian SPT PPh melalui sistem e-filling khusunya pada PNS/TNI/Polri.

b. Hendaknya prosedur penggunaan sistem e-filling lebih disederhanakan supaya sistem $e$-filling mudah dipelajari bagi Wajib Pajak yang belum pernah menggunakan sisteme-filling.

c. Bagi peneliti selanjutnya diharapkan dapat menambah jumlah sampel dan mengembangkan variabel yang sudah ada dalam penelitian ini,baik menambahkan variabel pemoderasi selain pemahaman internet, serta dapat menambahkan variabel intervening, agar hasil penelitian lebih bervariasi.

\section{DAFTAR PUSTAKA}

Abdul Rahman. (2010). Panduan Pelaksanaan Administrasi Perpajakan Untuk Karyawan, Pelaku Bisnis dan Perusahaan. Bandung: Nuansa .AdministrasiPerpajakan. Bandung: Nuansa

Adiasa, Nirawan. (2013). Pengaruh Pemahaman Peraturan Pajak Terhadap Kepatuhan Wajib Pajak Dengan Preferensi Risiko Sebagai Variabel Moderating”. Skripsi. Jurusan Akuntansi Universitas Negeri Semarang

Agustiningsih, Wulandari.(2016). Pengaruh Penerapan E-Filling, Tingkat Pemahaman Perpajakan dan Kesadaran Wajib Pajak Terhadap Kepatuhan Wajib Pajak di KPP Pratama Yogyakarta. Skripsi. Fakultas Ekonomi, Universitas Negeri Yogyakarta

Bambang Prasetyo dan L.M Jannah. (2005). Metode Penelitian Kuantitatif Teori dan Aplikasi. Depok: PT. Raja Grafindo Persada

Burton, Richard. “ Menuju Wajib Pajak Patuh”, Jurnal Perpajakan Indonesia, Volume 5 No 1 Agustus 2005

Dharma, K.S. (2011). Metodologi Penelitian Keperawatan. Jakarta: Trans Info Media

Diana Sari. (2013). Konsep Dasar Perpajakan. Bandung: PT.Refika Aditama 
Disperindag, DIY. (2017). Struktur Organisasi. Diambil dari http://disperindag.jogjaprov.go.id/struktur-organisasi.html pada tanggal 25 April 2017 jam 16:07 Wib

Disperindag, DIY. (2017). Visi dan Misi. Diambil dari http://disperindag.jogjaprov.go.id/visi-misi.html pada tanggal 25 April 2017 jam 16:09 Wib

Fatima Hayati, dkk. (2012). Kajian Aspek Perpajakan Wajib Pajak Orang Pribadi PNS dalam Pemenuhan Kewajiban Self Assesment (Studi Kasus Politeknik Negeri Jakarta). Jurnal Ekonomi dan Bisnis, Volume 11 No 2 Desember 2012

Haryono, Muhamad. (2012). Penegakan Hukumam Disiplin Berat Bagi Pegawai Negeri Sipil di Pemerintahan Kota Bandung Jawa Barat. Skripsi, Universitas Jenderal Soedirman, Purwokerto.

Husein Umar. (2011). Metode Penelitian untuk Skripsi dan Tesis Bisnis. Jakarta: PT Rajagrafindo Persada

Indriantoro, Nur dan Bambang Supomo. (2011). "Metodologi Penelitian Bisnis Untuk Akuntansi Dan Manajemen”, Edisi Pertama. BPFE,Yogyakarta

Juliansyah. (2011). Metodologi penelitian. Jakarta: Kencana prenada media group

Kirana, Gita Gowinda. (2010). "Analisis Perilaku Penerimaan Wajib Pajak Terhadap Penggunaan E-Filling"( Kajian Empiris di Wilayah Kota Semarang). Skripsi, Fakultas Ekonomi, Universitas Diponegoro, Semarang

Marsiasmo. (2016)."Perpajakan- esisi terbaru 2016". Penerbit ANDI. Yogyakarta: 2016

Nasucha. Chaizi. (2004). Reformasi Administrasi Publik: Teori dan Praktik. Jakarta: PT. Gramedia Widiasarana Indonesia.

Novarina, Ayu Ika. (2005). "Implementasi Electronic Filling System (E-Filling) dalam Praktik Penyampaian Surat Pemberitahuan (SPT) di Indonesia”. Tesis, Program Studi Pasca Sarjana Magister Kenotariatan, Universitas Diponegoro, Semarang

Nurhidayah, Sari. (2015). "Pengaruh Penerapan Sistem E-Filling terhadap Kepatuhan Wajib Pajak dengan Pemahaman Internet sebagai Variabel Pemoderasi pada KPP Pratama Klaten”. Skripsi, UNY, Yogyakarta

Pahala, Marihot, Siahaan. (2013). "Pajak Daerah dan Retribusi Daerah". Jakarta: Rajawali Pers

Purwanto Seno. (2017). 25 Persen ASN Busel Tidak Patuh Bayar Pajak. Diambil dari http://baubaupost.com/2017/02/02/25-persen-asn-busel-tidak-patuh-bayar-pajak pada tanggal 28 Februari 2017

Ramayanti, Renda.(2015). Pengaruh Penerapan Sistem E-Filling Terhadap Tingkat Kepatuhan Wajib Pajak: Studi Kasus Pada Kantor Pelayanan Pajak Pratama Bandung-Tegallega. Skripsi, Universitas Widyatama, Bandung

Riwidikdo, H. (2013). Statistik Kesehatan dengan Aplikasi SPSS dalam Prosedur Penelitian. Yogyakarta: Rohima Press 
Satriyo, Andika. 2009 "Pengaruh Reformasi Administrasi Perpajakan Terhadap Kepatuhan Wajib Pajak Pada Kantor Pelayanan Pajak (KPP) Pratama Jakarta Setiabudi Satu". Jurnal-jurnal Simposium Nasional Perpajakan 2, Universitas Pembangunan Veteran, Jakarta

Sialagan, Benny Perlaungan. (2016). Tingkat Kesadaran Kepatuhan Wajib Pajak di Kupang Rendah. Diambil dari http://bali.bisnis.com/read/20160404/10/58510/tingkat-kesadaran-kepatuhan-wajibpajak-di-kupang-rendah pada tanggal 28 Februari 2017

Sony Devano dan Siti Kurnia Rahayu. (2006). Pepajakan: Konsep, Teori dan Isu. Jakarta: Kencana.

Sugiyono. (2010). Metode Penelitian Kuantitatif Kualitatif dan R\&D. Bandung: Alfabeta (2012). Statistika untuk Penelitian. Bandung : Alfabeta.

Sukardji, Untung.(2005). Pajak Pertambahan Nilai, Edisi Revisi 2005. Jakarta: Grafindo Persada.

Tjahjono. (2006). Pengaruh Tingkat Kepuasan Atas Pelayanan Perpajakan Terhadap Tingkat Kepatuhan Wajib Pajak Orang Pribadi Pada Kantor Wilayah Direktorat Jenderal Pajak Jawa Bagian Timur I. Tesis, Universitas Airlangga, Surabaya.

Tresno,dkk. (2012). Pengaruh Persepsi Penerapan Sistem E-Filling Terhadap Tingkat Kepatuhan Wajib Pajak Badan Dengan Perilaku Wajib Pajak Sebagai Variabel Intervening dan Biaya Kepatuhan Sebagai Variabel Moderasi: Studi Kasus Pada KPP Pratama Pulogadung Jakarta Timur. Prosiding Simposium Nasional Perpajakan 4, Universitas Negeri Jakarta

Waluyo, dan Wirawan. (2010) . Perpajakan Indonesia. Jakarta: Salemba Empat

Widi Widodo dkk (2010). Moralitas, Budaya, dan Kepatuhan Pajak. Bandung. Alfabeta

Wikipedia. (2017). Penelitian Survai. Diambil dari https://id.wikipedia.org/wiki/Penelitian_survei pada tanggal 19 Februari 2017, jam $13: 54 \mathrm{Wib}$

Wikipedia, (2017). Pengertian Internet. Diambil dari https://id.wikipedia.org/wiki/Internet pada tanggal 01 Februari 2017, jam 10:12 Wib

Yunanto, Reza. (2015). “Analisis Kepatuhan Penyampaian Surat Pemberitahuan Pajak Penghasilan Wajib Pajak Orang Pribadi Sebelum Dan Sesudah Penerapan EFilling Melalui Website Direktorat Jenderal Pajak"(Studi Kasus di Kantor Pelayanan Pajak Sleman). Skripsi, Universitas Sanata Dharma, Yogyakarta

Peraturan Perundang-undangan:

Keputusan Direktur Jenderal Pajak Nomor Kep-88/PJ/2004 tentang Penyampaian Surat Pemberitahuan Secara Elektronik.

Pasal 1 Undang-Undang Nomor 16 tahun 2009 tentang Ketentuan Umum dan Tata Cara Perpajakan 
Pasal 2 ayat (1) Undang-undang NO.43 Tahun 1999 Tentang Pokok-pokok Kepegawaian.

Peraturan Menteri Keuangan Nomor 74/ PMK.03/2012. Tentang Syarat Menjadi Wajib Pajak Patuh.

Surat Edaran Kementerian Pendayagunaan Aparatur Negara dan Reformasi Birokrasi Nomor SE/02/M.PAN/3/2009 tanggal 31 Maret 2009 Tentang Wajib Penyampaian SPT melalui E-Filling bagi ASN/PNS/TNI dan Polri 